\title{
Food of young and colony-attendance of adult guillemots Uria aalge on Helgoland
}

\author{
M. F. Leopold ${ }^{1}$, P. A. Wolf ${ }^{1} \&$ O. Hüppop ${ }^{2, *}$ \\ ${ }^{1}$ Netherlands Institute for Sea Research; P.O. Box 59, NL-1790 AB, Den Burg, Texel, \\ The Netherlands \\ 2 Inselstation Helgoland des Instituts für Vogelforschung "Vogelwarte Helgoland"; \\ Postfach 1220, D-W-2192 Helgoland, Federal Republic of Germany
}

\begin{abstract}
The guillemot colony on Helgoland, Germany, was visited from June 5th to 21st 1990 . The presence of adults and food delivery to chicks was studied on a ledge holding about 50 breeding pairs. Attendance varied through the day, with most birds present at mid-day. Food consisted only of fish, $94.6 \%$ Clupeidae (herring and sprat) and $5.4 \%$ sand-eel. On average, a chick received 2.72 fish per day. After a marked early morning peak of feeding, the number of feeds per hour levelled off to a constant rate during the rest of the day until dusk. At sea, high numbers of guillemots were present in front of the colony, with densities dropping steeply with distance. The birds are thought to forage at distances of more than $5 \mathrm{~km}$ away from the colony.
\end{abstract}

\section{INTRODUCTION}

Helgoland $\left(54.11^{\circ} \mathrm{N}_{i} 7.55^{\circ} \mathrm{E}\right.$ ) is a small island (approx. $0.9 \mathrm{~km}^{2}$ ) with sandstone cliffs, rising up to about 60 metres above sea level, and has a seabird colony unique to the southeastern North Sea. It is the only place in this area where fulmars Fulmarus glacialis, kittiwakes Rissa tridactyla, razorbills Alca torda, and guillemots Uria aalge find cliffs to breed on. The colony has been doing well in the last two decades. Guillemot and kittiwake numbers increased rapidly from less than 1000 pairs in the seventies to over 2000 and over 4000 breeding pairs, respectively, today, and the fulmar now breeds with ca 30 pairs after it colonized Helgoland in the seventies (Moritz, 1980; Fleet, 1984; Voß et al., 1987; Prüter, 1989; Vauk et al., 1989). At present, numbers of kittiwakes, guillemots and fulmars are still increasing (Vogelwarte Helgoland). Only the razorbill breeding numbers have not increased, and today Helgoland has only about 6 pairs. The numbers of breeding guillemots have been increasing since at least 1970, and in 1986 the population was estimated to be some 2500 pairs (Vauk-Hentzelt et al., 1986; Vauk et al., 1989). This estimate is based on counts in June, with the number of breeding pairs assumed to be equal to the numbers of birds present in the colony at that time. This is an overestimate, due to the presence of off-duty breeders and non-breeding, prospecting sub-adults on the ledges. In 1990, more than 2000 chicks were counted jumping off the

\footnotetext{
- Addressee for all correspondence 
cliffs (Grunsky, 1992), so a present population size of about 2500 pairs seems a reasonable estimate. The increase of the breeding population is obvious, however, and the birds appear to have relatively little trouble in finding food in the vicinity of the island. This was the situation throughout most of the North Sea until the mid-eighties, but now there are indications that many colonies are no longer growing (Stowe, 1982; Benn et al., 1987; Lloyd, 1988; Rothery et al., 1988; Wanless \& Kinnear, 1988). Two explanations may be offered for the continuous growth of the Helgoland seabird colony. The colony may still be recovering from the massive hunting that took place until the beginning of this century (Weigold, 1910), and perhaps from the bombing of the island after World War II by the British. The numbers of large, predatory fish which may compete with seabirds for food have decreased as a result of human fisheries in the past decades. On top of this comes the present eutrophication of the German Bight, which also has its effect on the waters around Helgoland. Stocks of small prey fish may have increased, and as a result foraging conditions for seabirds could be improving (Vauk et al., 1989; Lozán et al., 1990).

With regard to the two common Helgoland seabird species, only the diet of the kittiwake has been studied in detail (Vauk \& Jokele, 1975; Vauk-Hentzelt \& Bachmann 1983; Vauk \& Prüter, 1987; Prüter, 1989; Hüppop, in prep.). The feeding ecology of the guillemots has surprisingly not been studied in detail, in spite of the uniqueness of the Helgoland colony. The only information on food comes from the examination of oilvictims in winter. Recorded prey were mainly Clupeidae and Ammodytidae, as well as some Gadidae and even flatfish (Vauk-Hentzelt, pers. comm.). There is very little published information on food and feeding in the breeding season. Müller (1869: cited by Hennicke, 1905) names herring and sprat as food brought to chicks, and Hennicke (1905: p. 220) mentions the presence of Ammodytes tobianus in stomachs of birds killed at Helgoland. Sea-going studies have not yet been undertaken in the vicinity of the island in the breeding season, and we do not know where the birds get their food.

The cliffs of Helgoland are very unstable, rendering the breeding ledges inaccessible to humans. Ringing of adult birds is not possible, but chicks can be caught when they jump off the cliffs after the rearing period. Catching takes place when dusk coincides with low tide, when a small tidal flat under the cliffs allows people to move about. Every year, up to a few hundred fledglings are ringed and weighed. Therefore, the only information yet available is on breeding numbers and dispersal. This paper presents information on the attendance pattern of the guillemots, the food they provide their young with; and body mass of departing chicks at Helgoland at the end of the breeding season. Some additional information is given on the distribution of the birds at sea and the general area where the fish may be caught.

\section{METHODS}

\section{Work in the colony}

The main part of the guillemot colony is on three cliffs on the southwest side of the island; these are not visible from any point on the island itself. In order to determine the food of young guillemots, we watched a ledge on the "Seliger Horn" at the southern end of the colony. This ledge is connected to the main cliffs, but is "around the corner", facing southeast. The ledge, at an elevation of 30 metres, can be viewed from both sea level and 
from nearby, on top of the cliff (approx. 50 and $125 \mathrm{~m}$ away). On average, 116 full-grown ("adult") guillemots were present on this ledge.

Two observers (ML, PW) made systematic observations from the concrete sea-wall at $4 \mathrm{~m}$ above sea level, from a site $52 \mathrm{~m}$ from the foot of the cliff, under the flight track of guillemots flying onto the ledge. Observation shifts usually lasted $3 \mathrm{~h}$ at a stretch, and were divided into $1 \mathrm{~h}$ units. We did morning $(5.00$ to 8.00 , or 6.00 to 9.00 Central European Summer Time), afternoon (12.00 to 15.00 , or 13.00 to 16.00$)$, and evening (18.00 to 21.00 , or 19.00 to 22.00 ) watches on six days in June 1990 (cf. Fig. 1). On the final

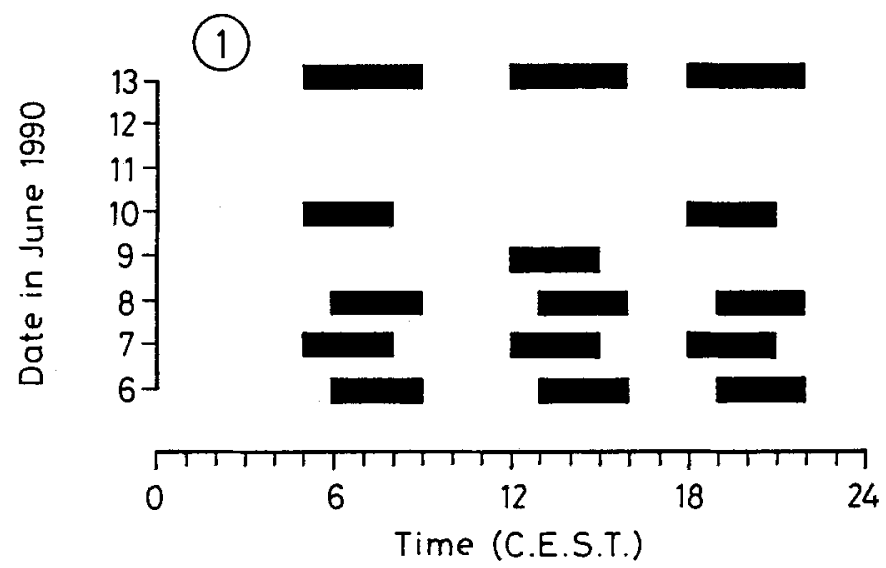

Fig. 1. Hours during which observations were made (black bars) and without observations (blank space). Time is Central European Summer Time (GMT +2 h)

observation day, the shifts lasted four hours. The number of young birds present on the ledge were counted from above (from the "Nuurder Moadek" and from the "Floagenberighorn") on June 10th and on June 14th.

At the start of each observation hour, we noted the number of "adults" present on the ledge. We recorded the number of landing guillemots, both with and without fish. "Touch and go landings" were ignored. Of each fish brought, we tried to determine species or group; we estimated its size, and one observer followed its fate. The fish were classed as either "fed to young", or "used in display". All fishes that were not fed to young, but swallowed by the carrier, given to or stolen by another bird, or dropped were classed as "display fish". Birds landing with fish and leaving again with that fish were excluded, as many of these were seen to come back shortly after, still carrying the fish. Only the final landing was recorded in such cases. Fishes were considered to be given to a chick if the chick was seen eating the fish, or if adult behaviour showed that a chick had been fed. Adults feeding chicks shield the fish and the chick by dropping their wings and arching their back; this behaviour makes direct observations difficult. However, if a bird that had been displaying this behaviour was seen with an empty bill when it resumed normal posture, the fish was considered to have been fed to a chick. Sometimes, two adults showed this back-arching together. Then both birds were watched to check if the fish was not used in display and taken over by the other bird. If this did happen, but the other bird fed the fish to a chick, it was classed as "fed to chick". 
Towards the end of the season, on June 20th and 26th, two whole-day counts were made from dawn to dusk, to assess the influence of the tidal cycle on the numbers of birds present on the ledge.

\section{Work at sea}

Guillemot density at sea around the breeding colony was assessed by ship-based counts. No research vessel was available for this purpose, so ships that chanced to be plying near this area had to be used. We counted seabirds at sea from the ferry "Wilhelmshaven" between Wilhelmshaven and Helgoland on June 5th and 21st. This ship is $76 \mathrm{~m}$ long and has an observers' platform $7 \mathrm{~m}$ above sea level. On June 12th and 15th we made short trips on the research vessel "Uthörn", in waters to the south and southwest of the island. This ship measures $30 \mathrm{~m}$ and observer's eye-height is $7 \mathrm{~m}$. Finally, we counted from the "Aade", an $11 \mathrm{~m}$ long and $2 \mathrm{~m}$ high research sloop, when it visited the coastal waters south, west and northwest of Helgoland on June 18th and 19th. Methods used were principally those described in Tasker et al. (1984). Only from the Aade did we not count the usual $300 \mathrm{~m}$ wide band transect on one side of the ship. Due to the low height of this boat, we took a strip of $200 \mathrm{~m}$ width, divided into two strips of $100 \mathrm{~m}$ at each side of the ship. Weather conditions were good during all ship counts: windforces of 3-4 Beaufort on the ferry and the Uthörn, and force $0-2$ B on the Aade. Guillemots sitting at sea in front of the colony were observed from the top of the cliffs. Flying directions of birds coming in with fish were noted during short watches from lookout positions at the top of the cliffs.

\section{RESULTS}

\section{Numbers present and landing on the ledge}

Numbers of "adults" present on the ledge varied between 93 and 132. No statistical difference was found between numbers present and date (ANOVA, $p=0.19$ ). The lowest numbers were counted in the early morning and the late evening (Mean $\pm 1 \mathrm{SD}: \overline{\mathrm{x}}=103$ $\pm 9.2 ; \mathrm{n}=3$, at 5.00 a.m., and $\overline{\mathrm{x}}=101 \pm 11.8 ; \mathrm{n}=3$, at 9.00 p.m.). The highest numbers were present on the ledge during the afternoon watches; $\vec{x}=123 \pm 6.3 ; n=15$ (ANOVA, $\mathrm{p}=0.002$; Fig. 2). Therefore, a relatively high number of off-duty birds and even prospecting non-breeders were present during mid-day. That non-breeders were involved is shown by the numbers of young on the ledge. On June 10 th, we counted 50 chicks and 3 eggs. The same numbers were seen on June 14 th (may be one egg had fallen off). Thus, theoretically, 106 parents at the most could have been on the ledge at any one time. It has been shown elsewhere that parent birds only spend about $30 \%$ of their off-duty time on the breeding ledge (Harris \& Wanless, 1985); so, probably only about 70 of the "adults" on the ledge were breeders. Another indication of the involvement of non-breeding birds were the high numbers of birds landing on the ledge without fish. These landings were recorded from the second observation day onward. There was no trend in the numbers landing within the first four observation days. Numbers of birds landing without fish during afternoon and evening hours did not differ, so these results were pooled: on average $83.3 \pm 15.1(n=18)$ birds landed per hour. In the morning hours, fewer birds were recorded landing without fish: $67.2 \pm 9.1(n=9)$. This difference 


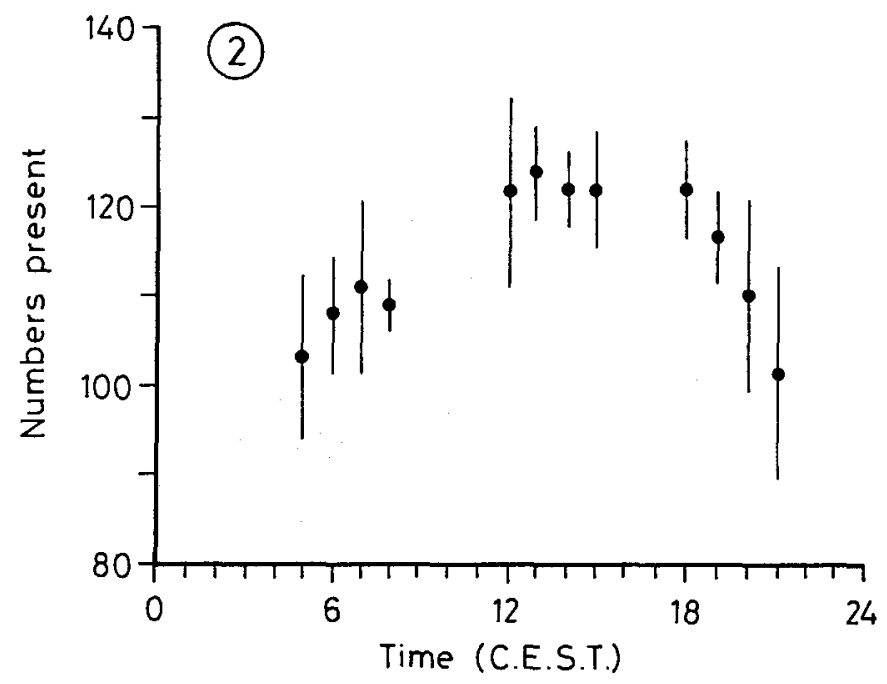

Fig. 2. Mean numbers ( $\pm 1 \mathrm{SD}$ ) of "adult" guillemots present on the ledge at the start of each observation hour

is significant: $t$-test, $t=2.972, \mathrm{p}<0.01$. During the last observation day, however, the number of landings was higher: morning: $79.3 \pm 11.0(n=4)$; afternoon: $137.3 \pm 14.1$ $(\mathrm{n}=4)$; evening: $131.3 \pm 26.8(\mathrm{n}=4)$.

\section{Numbers of fish brought to the ledge}

During the first observation hour, there was a marked peak of feeding, as well as displaying (Fig. 3a, b). The chicks got more than 3 times as many fish then, compared to the hours after $7.00 \mathrm{a}$.m. The hour from 6.00 to 7.00 was intermediate in this respect. After $7.00 \mathrm{a}$.m., the rate at which fish were carried in dropped to a steady rate of about 7.2 per hour, of which on average 6.4 were fed to the chicks. Given this uniformity, we may assume that in the hours without observations, between 9.00 and 12.00 and between 16.00 and 18.00 hours, the feeding rate was also on average 6.4 fish per hour. We have some information on the rate at which fish were brought in before our observations started at 5.00 and after we stopped at 22.00 . On June 14 th, we watched the birds on the ledge from 04.15 to 05.00 , and noted the first delivery at 4.30 . In the half hour that followed, we recorded 6 feedings and 3 fishes used in display. During the ringing of chicks at dusk, we noted a rather low delivery rate. The birds seemed to stop bringing fish altogether after 22.45. Therefore, we assume that on average 3 fish were fed to the chicks on the study ledge after 22.00. Taking the values of 6 and 3 feedings before and after our watches, respectively, we arrive at a total of 136 fishes fed to the young per day, or 2.72 fish per young per day.

The numbers of fish used in display showed an even more extreme morning peak, with an average of 8.3 fish used in the first observation hour. During the morning, the rate dropped fast, and in the afternoon and evening hours, less than one fish per hour was used in display. In total, 162 fish are calculated to have been carried to the ledge per day. 

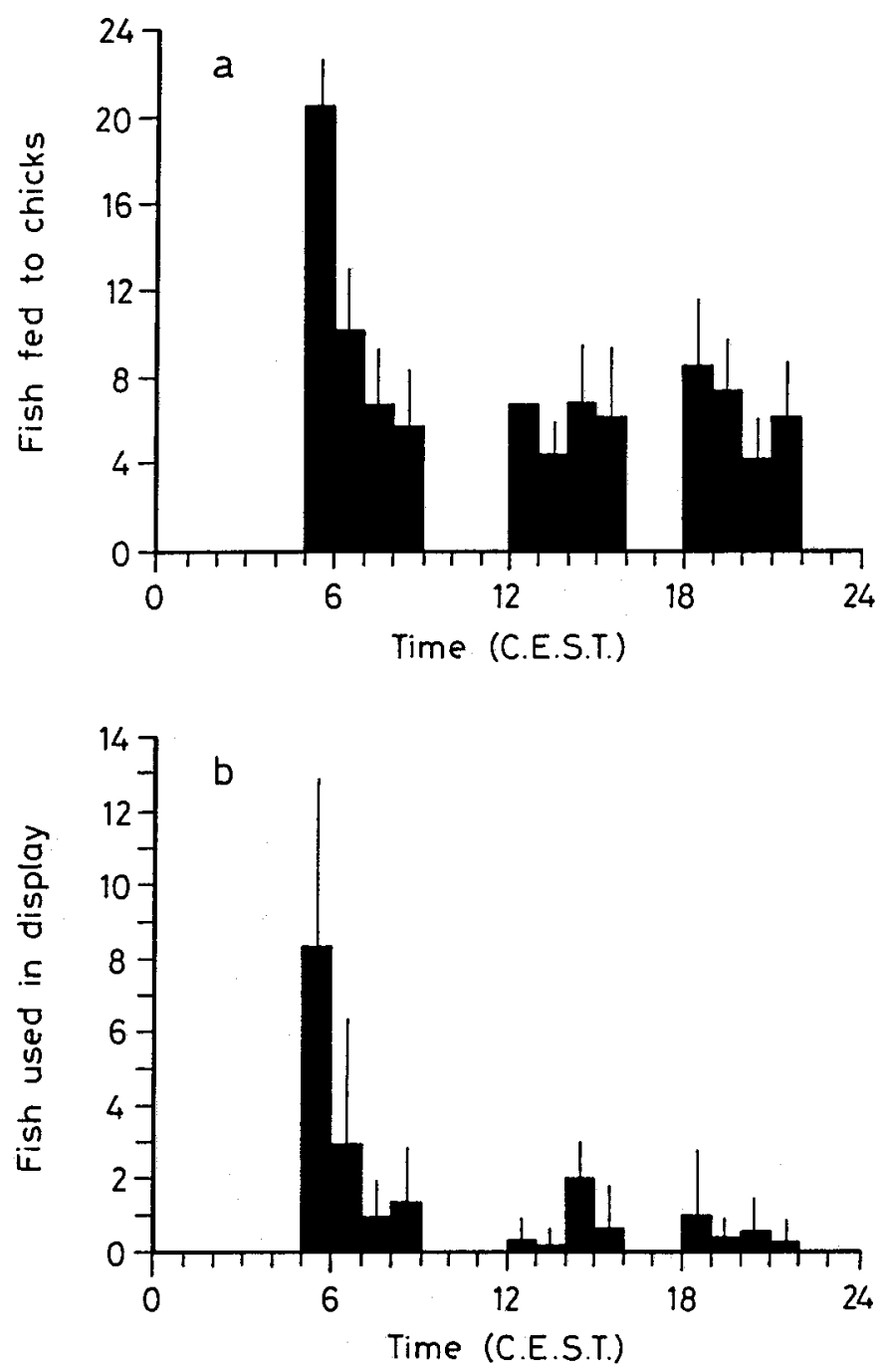

Fig. 3a. Mean numbers ( $\pm 1 \mathrm{SD}$ ) of fish brought per hour to the ledge and fed to the chicks Fig. 3b. Mean numbers ( $\pm 1 \mathrm{SD}$ ) of fish brought per hour to the ledge and used in display

\section{Species and sizes of prey}

No prey items other than fish were seen. In total, 442 fish were recorded, of which 402 were clupeids, either sprat Sprattus sprattus or herring Clupea harengus, and 23 were sand-eel Ammodytes spec. A more precise distinction was often not possible. From a distance of over 50 metres, sprat and herring look very much alike. Both sprat (rather greyish back, high and relatively flat body) and herring (blue back and rounder body) were positively identified, and the majority ( $79 \%$ of 38 ) appeared to be sprat. A small number of fish $(n=17)$ could not be identified, because sometimes a parent moved too 
quickly for us to see the fish well enough. We have no indication that any of these were other species than those mentioned above. Some (display) fish were dropped by the birds. We found 5 sprat $(10,10,11,11$ and $14 \mathrm{~cm})$ and 2 herring $(10$ and $14 \mathrm{~cm})$ under the study ledge, and two more sprat (both $11 \mathrm{~cm}$ ) under other ledges. Also 2 lesser sand-eels Ammodytes lancea (17 and $18 \mathrm{~cm}$ ) were found under our ledge.

Fish sizes were estimated by comparing them to the bird's total head length (ca $11 \mathrm{~cm}$ ). The clupeids ranged from 9 to $15 \mathrm{~cm}$, with the bulk being 10 to $12 \mathrm{~cm}$. Estimated sizes of fish fed to young and used in display averaged $11.2 \mathrm{~cm}(\mathrm{n}=383)$ and $11.1 \mathrm{~cm}$ $(\mathrm{n}=67$ ), respectively. Estimation of sand-eel size was more difficult, because a larger part of the fishes' bodies were down in the birds' throats, and the body shape of a sandeel gives little indication as to where its head may be. Most sand-eels brought to the ledge were classed as $15-20 \mathrm{~cm}$. Twenty of these large sand-eels were recorded, out of which 18 were fed to young. Three small $(8-12 \mathrm{~cm})$ sand-eels were recorded, of which one was used in display.

\section{Numbers of chicks fledging, and their body masses}

In the 1990 season, numbers of jumping guillemots were counted daily (Grunsky, 1992) between June 5th and July 3rd, with the exception of June 15th and July 1st. In total, about 2070 chicks were seen to jump, with the highest numbers around June 12th. Body masses of 189 ringed chicks varied between 185 and $325 \mathrm{~g}$, as measured by a Pesola spring balance to the nearest $5 \mathrm{~g}$. The mean ( $\pm 1 \mathrm{SD}$ ) body mass of $256 \pm 29.1 \mathrm{~g}$ seems normal for the colony, when compared to data for the other years of which we have data (see Table 1).

Table 1. Mean body mass of guillemot fledglings on Helgoland. Chicks were caught immediately after they jumped off their breeding ledges, and weighed to the nearest $5 \mathrm{~g}$

\begin{tabular}{|rrccc|}
\hline Year & $\mathrm{n}$ & Mean $(\mathrm{g})$ & $\mathrm{SD}$ & Range \\
\hline 1976 & 16 & 222 & 23.8 & $180-260$ \\
1986 & 83 & 261 & 31.3 & $175-350$ \\
1987 & 5 & 216 & 34.7 & $175-255$ \\
1989 & 122 & 240 & 25.0 & $175-295$ \\
1990 & 189 & 256 & 29.1 & $185-325$ \\
\hline
\end{tabular}

\section{Guillemots at sea}

The transects counted at sea are depicted in Fig. 4a. The area surveyed was divided into rectangles of $2^{\prime}$ latitude $\times 3^{\prime}$ longitude, and guillemot densities were calculated for each rectangle visited (Fig. $4 \mathrm{~b}$ ). Guillemot numbers at sea were high directly in front of the colony, where over 100 birds per $\mathrm{km}^{2}$ were present. Observations from the cliff-tops showed that the birds did not forage here. Instead, the birds used this area for resting, bathing and preening, and social activities (Leopold et al., 1990). Further away from the colony, guillemot numbers decreased rapidly in all directions surveyed. However, of the vessels used in the survey, only the ferry took us into waters at a considerable distance 


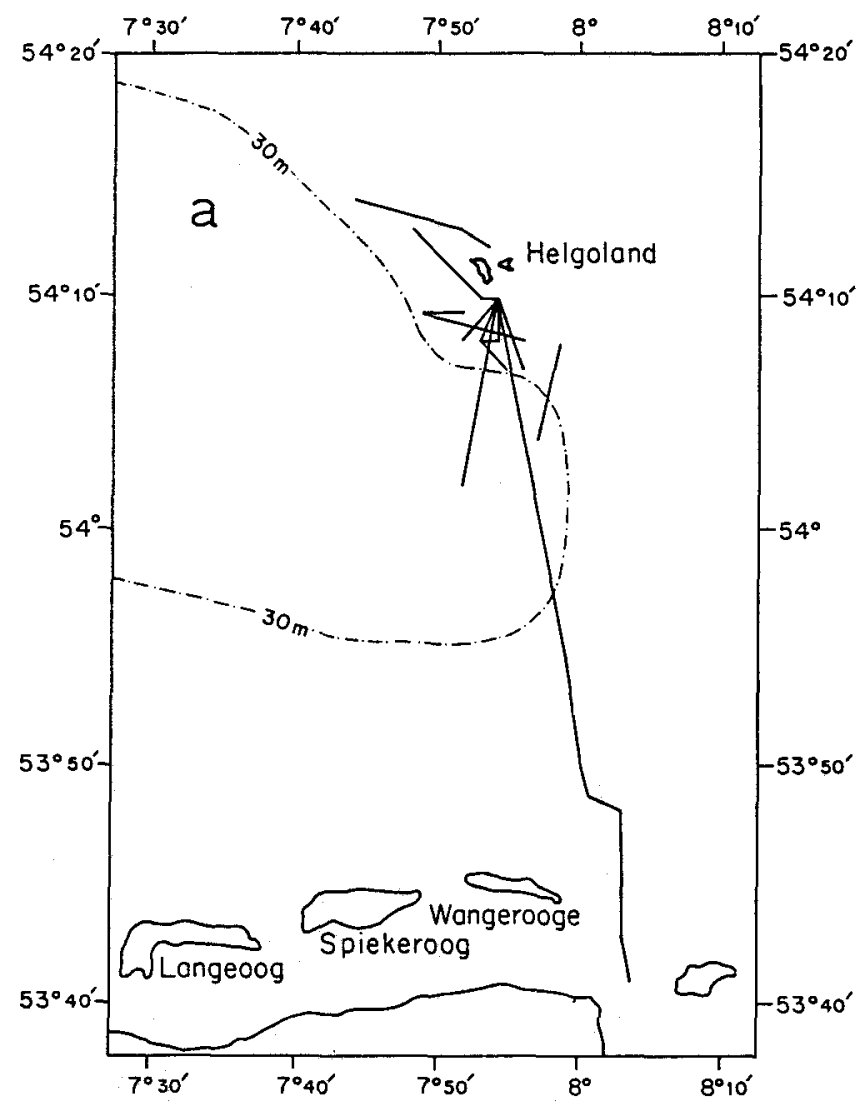

Fig. 4a. Transects (thin lines) surveyed in Helgoland waters, June 1990. The longest transect represents the ferry-route, and was counted twice, on June 5th and 21st. All other transects were counted once, between these two dates

from the colony (to the south). In the shallow coastal waters south of Helgoland no guillemots were found. Waters to the east and deeper waters to the west and north of Helgoland could not be surveyed, and it remains uncertain where the birds had their foraging area(s). From the cliff-tops, facing southwest, birds were seen ferrying fish in from all directions between south and northwest. At sea, however, birds flying towards the colony with fish in their bills were regularly seen south and west of Helgoland, but not during one hour of observation at a station in the most northwestern sector of our surveyed area. These results indicate that most guillemots foraged at distances beyond the present area surveyed, i.e. further than $5 \mathrm{~km}$ away from the colony, probably mainly south and west of the island. Some birds accompanying chicks were seen, all of them south of Helgoland. 


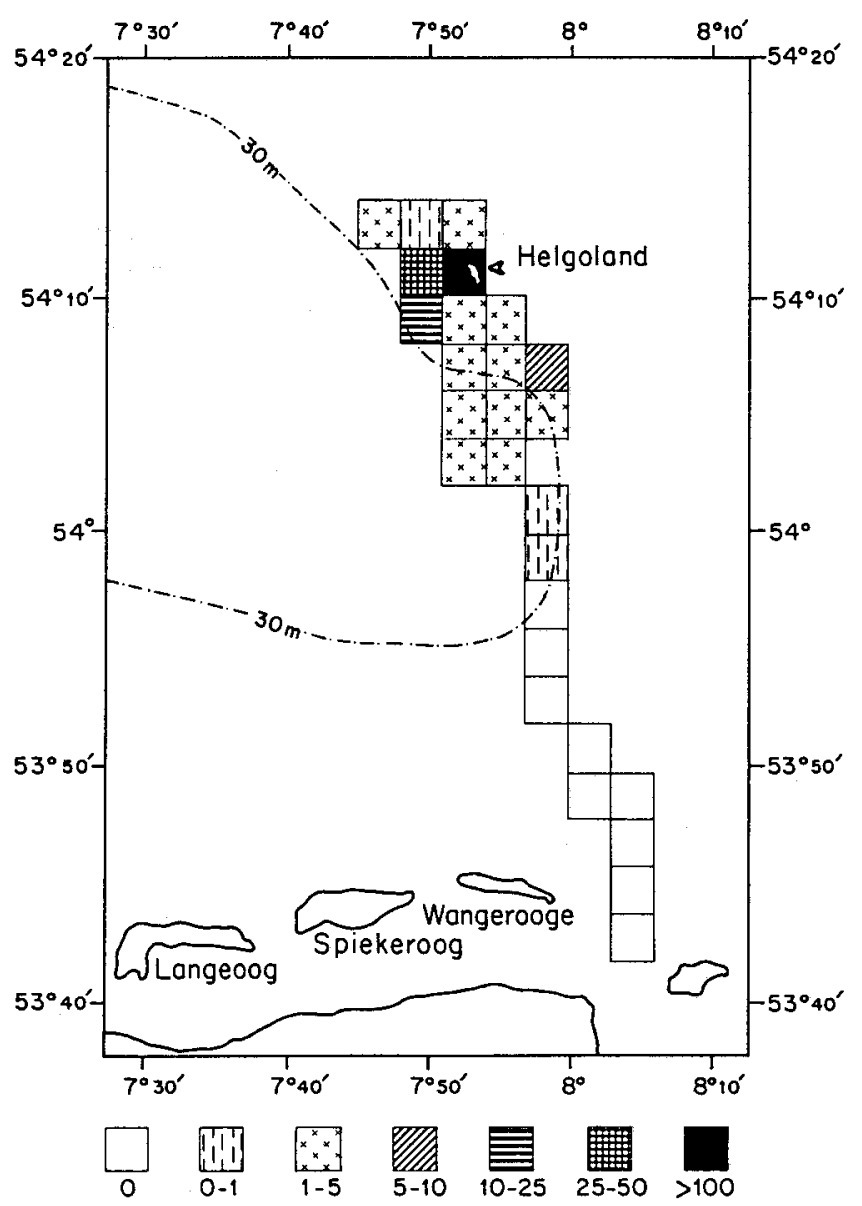

Fig. 4b. Guillemot densities around Helgoland during the chick period

\section{DISCUSSION}

The study ledge

Study plots are usually chosen on the basis of their accessibility, and are therefore not always fully representative of the colony. In our case an objective selection could not be made, as the main part of the colony is only visible from the water. Thus, a study ledge that was situated at the edge of the colony had to be chosen. Peripheral sections of bird colonies have been shown to hold lower quality birds that breed later and produce fewer and less viable young (cf. Coulson, 1968). Two of our observations indicate that our birds were slightly below average quality. In the main part of the colony, about $45 \%$ of the chicks had already fledged by June 14th (Grunsky, 1992), whereas on the study ledge the first chicks fledged on June 14th. Apart from this relatively late fledging date, the high 
number of non-breeders on the ledge may also indicate that the ledge is a sub-optimal locality. The ratio of breeding pairs:individuals present (referred to as "k-factor" by Birkhead, 1978) was $53: 116=0.46$. This is considerably lower than the $\mathrm{k}$-factors found for other colonies, which range from $0.65-0.70$. However, the $k$-factor for the colony as a whole is not known, and colonies that increase in size probably have many sub-adult non-breeders present on the ledges (Birkhead, 1978). In conclusion, the ledge probably hosted late breeders in the company of many prospecting non-breeders. This does not necessarily imply that the breeders themselves were of low quality. In guillemots, breeding success is mainly density dependent, and groups of late breeders have average reproductive output (Wanless \& Harris, 1988). Therefore we assume that, apart from the fledging date, the breeding performance on the study ledge was little different from that in the rest of the colony.

\section{Tidal and daily rhythms}

There may have been a tidal influence on the numbers of birds present and landing on the ledge during the day. Such a tidal rhythm in guillemots was found by Slater (1976, 1980). Our data-set is too small to assess tidal influences properly, as all high tides were in the afternoon hours. Therefore, the relatively high numbers present during the afternoon hours, could be both time- and tide-related. To evaluate the possible influence of tide on the numbers present on the ledge, two additional, whole day counts were conducted on June 20th and 26th. By this time, most young had fledged, but "adult" birds were still present in fair numbers. On June 20th, two large and three small pulli, as well as one egg were still present. On the 26 th, the two large pulli had fledged, but the three small ones (and the egg) still remained. The phase of the tidal cycle differed on these two days: June 20 th had low tide in the afternoon, whereas June 26 th had high tide then. On both days, the numbers present followed basically a hyperbolic function of time (Fig. 5). With the

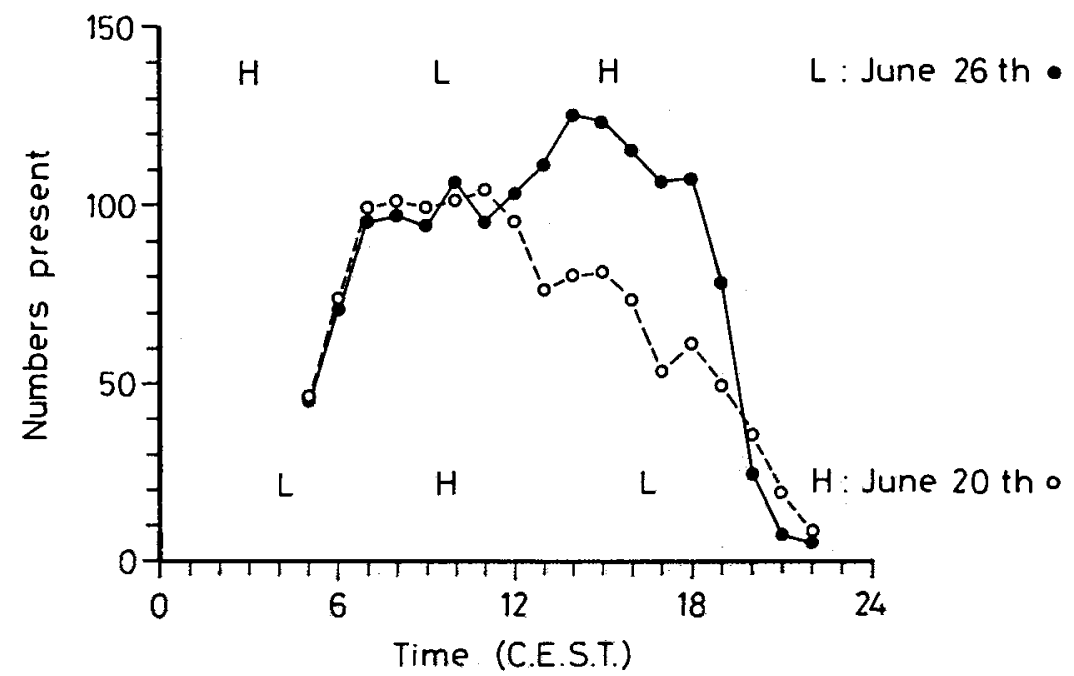

Fig. 5. Numbers of "adult" guillemots present on the study ledge on June 20th and 26th. Times of high and low water on both days are indicated $(H, L)$ 
afternoon high tide, the curve showed an upward deviation and with the afternoon low tide a downward deviation. Earlier in the season, a similar dip in the presence of guillemots around mid-day low water was found during a single all-day count by Preller et al. (1979). It appears, therefore, that on Helgoland there is a tidal influence superimposed on the daily pattern in numbers present. Tidal influences on guillemot attendance patterns in other colonies have only been found early in the breeding season, not during the chick-stage (Slater, 1976, 1980; Piatt \& McLagan, 1987).

The number of landings with fish appear to be mainly related to the time of day. A marked peak in birds landing with fish (Fig. 3) was seen in early morning of every observation day. Half a tidal cycle later (in the evening hours), such a peak was never observed, from which it can be concluded that the early morning peak in feedings was not governed by the tide. Similar early morning peaks in feeding activity have been found in other guillemot colonies as well (Bradstreet \& Brown 1985; Harris \& Wanless, $1985,1986)$. Landings without fish were equally frequent in the afternoon and evening watches, and are therefore also unrelated to the tide. The influence of weather is not considered here. The weather was calm on all the observation days, with hardly any rain. Only in the morning and evening of June 9th was there heavy rain, but then no observations were made.

\section{Prey}

Clupeidae and Ammodytidae are the main prey species in western European guillemot colonies studied. Sand-eel are most important in the Shetland/Orkney colonies (Furness, 1989; Harvey et al., 1990). With increasing distance from this area, the proportion of clupeids appears to increase (Bradstreet \& Brown, 1985; Harris \& Wanless, 1985: Table II). Helgoland is no exception to this pattern, with $94.6 \%$ clupeids and $5.4 \%$ sand-eel. The sizes of fish were also within the ranges reported elsewhere, although the average sand-eel size was large on Helgoland. The number of fish given to each chick were 0.15 sand-eel and 2.58 clupeid per day. A rough calculation, based on estimated fish length and the Harris \& Hislop (1978) relationships for sprat and sand-eel (all clupeids considered equal to British sprat), gives a daily intake per chick of $27.2 \mathrm{~g}$ of fish, or $286 \mathrm{~kJ}$. This is similar to figures for other colonies where sprat is the main prey: Skomer, $28 \mathrm{~g}$ (Birkhead, 1977) and Stora Karlsö, $32 \mathrm{~g}$ (Hedgren \& Linnman, 1979). However, higher daily intakes have also been reported for guillemot chicks. For example, on the Isle of May the chicks received mainly large sand-eel, and were calculated to obtain on average $345 \mathrm{~kJ}$ per day in 1982-84 (Harris \& Wanless, 1985). Obviously, care is needed when caloric intakes in different colonies are compared, while actual measurements of the caloric values of the prey fish are missing and one has to rely on regressions determined elsewhere, in another year.

\section{Location of the feeding grounds}

The foraging range and main feeding grounds were not found during this study, and it will need a dedicated survey to study these properly. Breeding guillemots can fly considerable distances to get food. Although guillemots of Fair Isle remained mainly within $6 \mathrm{~km}$ of the island (Blake et al., 1984: appendix C), on Skomer they were thought to travel at least $10 \mathrm{~km}$ (Bradstreet \& Brown, 1985). Guillemots have also been seen flying 
with fish to colonies ca $50 \mathrm{~km}$ away (Joiris, 1978; Leaper et al., 1987). Obviously, more work around Helgoland is needed to clarify the at-sea-distribution of its seabirds.

Acknowledgements. We would like to thank B. Grunsky, B. Wilkening, and B. Wächter for assistance during the all-day counts; ${ }_{i}$ G. Tadday for enabling us to work on the ships of the Biologische Anstalt Helgoland; and Captains Klings, Krawinkel and Röw for letting us work on their ships.

\section{LITERATURE CITED}

Benn, S., Tasker, M. L. \& Reid, A., 1987. Changes in numbers of cliff-breeding seabirds in Orkney, 1976-1985. - Seabird 10, 51-57.

Birkhead, T. R., 1977. Adaptive significance of the nestling pøriod of guillemots Uria aalge. - Ibis $119,544-549$.

Birkhead, T. R., 1978. Attendance patterns of guillemots Uria aalge at breeding colonies on Skomer Island. - Ibis 120, 219-229.

Blake, B. F., Tasker, M. L., Jones, P. H., Dixon, T. J., Mitchell, R. \& Langslow; D. R., 1984. Seabird distribution in the North Sea. Nature Conservancy Council, Huntingdon, $336 \mathrm{pp}$.

Bradstreet, M. S. W. \& Brown, R. G. B., 1985. In: The Atlantic Alcidae. Ed. by D. N. Nettleship \& T. R. Birkhead. Acad. Press, London, 574 pp.

Coulson, J. C., 1968. Differences in the quality of birds nesting in the centre and on the edges of a colony. - Nature, Lond. 217, 478-479.

Fleet, D. M., 1984. Changes in the numbers of breeding kittiwakes in Helgoland. - Ringing Migr. 5 , 32-34.

Furness, R. W., 1989. Changes in diet and breeding ecology in seabirds on Foula, 1971-88. In: Seabirds and sandeels. Ed. by M. Heubeck. Shetland Bird Club, Leswick, Shetland, 22-26.

Grunsky, B., 1992. Anwesenheit adulter Trottellummen (Uria aalge) in der Brutkolonie auf Helgoland, Bestandsermittlung und Nahrungsökologie ihrer Jungen. Dipl. Arb., Univ. Bonn, 93 pp.

Harris, M. P. \& Hislop, J. R. G., 1978. The food of young puffins Fratercula arctica. - J. Zool., Lond. $185,213-236$.

Harris, M. P. \& Wanless, S., 1985. Fish fed to young guillemots, Uria aalge, and used in display on the Isle of May, Scotland. - J. Zool., Lond. 207, 441-458.

Harris, M. P. \& Wanless, S., 1986. The food of young razorbills on the Isle of May and a comparison with that of young guillemots and puffins. - Ornis Scand. 17, 41-46.

Harvey, P. V., Harris, M. P., Osborn, K., Riddiford, N. \& Silcocks, A. F., 1990. The breeding success and diet of Fair Isle's seabirds in 1986-1989. - Fair Isle Bird Observatory Rep. 42, 47-54.

Hedgren, S. \& Linnman, A., 1979. Growth of guillemot Uria aalge chicks in relation to time of hatching. - Ornis Scand. 10, 29-36.

Hennicke, C. R. (Hrsg.), 1905. Naumann, Naturgeschichte der Vögel Mitteleuropas. Köhler, GeraUntermhaus, 12, 1-274.

Joiris, C., 1978. Seabirds recorded in the northern North Sea in July: the ecological implications of their distribution. - Gerfaut $68,419-440$.

Leaper, G. M., Webb, A., Benn, S., Prendergast, H. D. V., Tasker, M. L. \& Schofield, R., 1987. Seabird studies around St Kilda, June 1987. - NCC-Rep. 804, 1-83.

Leopold, M. F., Wolf, P. A. \& Laks, M. H., 1990. Zeekoeten op een drijvende klif. - Sula 4, 100-103.

Lloyd, C. S., 1988. Progress with the seabird colony register. - Seabird Group Newsl. 53, 3-4.

Lozán, J. L., Lenz, W., Rachor, E., Watermann, B. \& Westernhagen, H. von, 1990. Warnsignale aus der Nordsee. Parey, Berlin, $432 \mathrm{pp}$.

Moritz, D., 1980. Das Brutvorkommen des Eissturmvogels (Fulmarus glacialis) auf Helgoland. Angew. Ornithol. 5, 149-177.

Piatt, J. F. \& McLagan, R. L., 1987. Common murre (Uria aalge) attendance patterns at Cape St. Mary's, Newfoundland. - Can. J. Zool. 65, 1530-1534.

Preller, H., Roussos, E. \& Stork, H.-J., 1979. Ganztagsbeobachtung am Helgoländer Vogelfelsen. Beitr. Vogelforsch. 6, 121-126.

Prüter, J., 1989. Phänologie und Ernährungsökologie der Dreizehenmöwen-(Rissa tridactyla-)Brutpopulation auf Helgoland. - Ökol. Vögel 11, 189-200. 
Rothery, P., Wanless, S. \& Harris, M. P., 1988. Analysis of counts from monitoring guillemots in Britain and Ireland. - J. Anim. Ecol. 57, 1-19.

Slater, P. J. B., 1976. Tidal rhythm in a seabird. - Nature, Lond. 264, 636-638.

Slater, P. J. B., 1980. Factors affecting the numbers of guillemots Uria aalge present on cliffs. - Ornis Scand. 11, 155-163.

Stowe, T. J., 1982. Recent population trends in cliff-breeding seabirds in Britain and Ireland. - Ibis $124,502-510$.

Tasker, M. L., Jones, P. H., Dixon, T. J. \& Blake, B. F., 1984. Counting seabirds from ships: a review of methods employed and a suggestion for a standardized approach. - Auk 101, 567-577.

Vauk, G. \& Jokele, I., 1975. Vorkommen, Herkunft und Winternahrung Helgoländer Dreizehenmöwen (Rissa tridactyla). - Veröff. Inst. Meeresforsch. Bremerh. 15, 69-77.

Vauk, G. \& Prüter, J., 1987. Möwen: Arten, Bestände, Verbreitung, Probleme. Niederelbe-Verl., Otterndorf, $303 \mathrm{pp}$.

Vauk, G., Prüter, J. \& Hartwig, E., 1989. Long-term population dynamics of breeding bird species in the German Wadden Sea area. - Helgoländer Meeresunters. 43, 357-365.

Vauk-Hentzelt, E. \& Bachmann, L., 1983. Zur Ernährung nestjunger Dreizehenmöwen (Rissa tridactyla) aus der Kolonie des Helgoländer Lummenfelsens. - Seevögel 4, 42-45.

Vauk-Hentzelt, E., Schrey, E. \& Vauk, G., 1986. Bestandsentwicklung der Trottellumme (Uria aalge) auf Helgoland 1956-1984. - Seevögel 7, 40-45.

Voß, M., Hartwig, E. \& Vauk, G., 1987. Untersuchungen zum Nahrungsverbrauch der Dreizehenmöwen (Rissa tridactyla) auf Helgoland an handaufgezogenen Jungtieren. - Seevögel 8, 5-13.

Wanless, S. \& Harris, M. P., 1988. The importance of relative laying date on breeding success of the guillemot Uria aalge. - Ornis Scand. 19, 205-211.

Wanless, S. \& Kinnear, P. K., 1988. Recent changes in the numbers of some cliff-nesting seabirds on the Isle of May. - Bird Study 35, 181-190.

Weigold, H., 1910. Die diesjährige Lummen-"Jagd" auf Helgoland. - Orn. Mschr. 35, 363. 